\title{
Familial Mediterranean Fever Cases in Turkey
}

\author{
Ayla San* \\ Internal Diseases and Nephrology Specialist, Ankara, Turkey
}

*Corresponding author: Ayla San, Internal Diseases and Nephrology Specialist, Emek 29 Street Kose Apt 9/1 Ankara 06510, Turkey, Tel: +90 312 213 9880; E-mail: ayla.san29@gmail.com

Received: 23 Mar, 2020 | Accepted: 17 Aug, 2020 | Published: 21 Aug, 2020

Citation: San A (2020) Familial Mediterranean Fever Cases in Turkey. Int J Nephrol Kidney Fail 6(3): dx.doi.org/10.16966/2380-5498.200

Copyright: (c) 2020 San A. This is an open-access article distributed under the terms of the Creative Commons Attribution License, which permits unrestricted use, distribution, and reproduction in any medium, provided the original author and source are credited.

\section{Abstract}

Familial Mediterranean Fever (FMF) is a hereditary auto inflammatory disease. The most common symptoms are high fever, abdominal pain and arthralgia. An inflammatory condition occurs in the body due to a gene disorder called MEFV and thus the immune system cannot overcome the situation.

FMF is a disease requiring life-long treatment in which medicine called Colchicine is commonly used. Regular use of Colchicine also prevents the development of kidney failure due to the accumulation of amyloid, a harmful protein. The most common primary etiological cause in the diagnosis of AA amyloidosis is found to be FMF (57\%).

In FMF patients, M694V mutation in which the disease onsets at an earlier age, the severity is higher and amyloidosis is more commonly seen.

In this study, an evaluation of the articles published on FMF from past to present has been made. A total of 16,927 people were included in the study. Of these, 2,421 were females and 1,708 were males. A total of 625 pregnant women diagnosed with FMF were included in three studies conducted on FMF and pregnancy.

In other studies, other diseases such as Polyarteritis Nodosa (PAN), Celiac Disease, Immunoglobulin A Vasculitis /Henoch-Schönlein Purpura (IgAV/ HSP), Protracted Fibromyalgia Syndrome (PFMS) and Hidradenitis Supportive (HS) can be observed together with FMF.

Although FMF has existed in Anatolia, Caucasia and the Middle East for several thousand years, it was not recognized as a clinical entity up until 1945. The disease was first published in the Turkish medical literature in 1946, but its relationship with FMF type "secondary" amyloidosis was documented in 1950's and colchicine was discovered to treat FMF in 1972. FMF became an even more interesting disease as its gene MEFV and the protein encoded by this gene (pyrin/marenostrin) were discovered in 1997 simultaneously by two independent groups. It was soon found out that pyrin had some structural similarities to death domains of certain proteins taking part in apoptosis, and FMF was included in a new group of diseases which somewhat resembled each other with recurrent inflammatory attacks: the auto inflammatory diseases.

\section{Introduction}

FMF is a hereditary autoinflammatory disease characterized by recurrent fever and synovial inflammation in the form of peritonitis, pleuritis and/or localized inflammatory attacks on the skin in the form of Erysipelas-Like Erythema [1].

FMF is defined as the disease of the Mediterranean Basin, first observed in Jewish and Armenian patients, and was later identified among Turks and Arabs [2]. The Jews, who migrated from Spain in 1492, later entered the Ottoman Empire, spreading the disease through migration [3] (Figure 1).

Janeway and Rosenthal reported on a 16 year-old patient with recurrent fever, abdominal pain, leukocytosis which was accepted as the first FMF case reported in the world. In 1945, American researcher Siegel described a clinical picture with similar complaints called "Benign Paroxysmal Peritonitis" [4-6,8] (Figure 2).
In 1948, Reiman used the term "Periodic Disease". In 1951, Catton and Mamoru first discovered FMF was familial and highlighted its genetic transition with amyloidosis in 1956. The definition of FMF was used in 1958 by Heller and Sohar as Mediterranean origin. In 1997, International FMF Consortium and French FMF Consortium identified the MEFV gene responsible for the disease (Figure 3).

In Turkey, Abravaya Marmaralı identified FMF in an adult as "Strange Abdominal Pain Syndrome" in 1946. The benefits of Colchicine in FMF treatment were first demonstrated by Emir Özkan and Goldfinger in 1972.

In the study by Özdemir AL and Sökmen C between 1958-1968, the rate of FMF was $0.3 \%$ [9]. In the study by Özen $S$ et al., in 1998, the rate of FMF patients was 2.3/10,000, and that of potential FMF patients was 9.3/10,000 [10]. 
In Turkey, in 1989, Ilhan I, et al., described the association between FMF and Polyarteritis Nodosa (PAN) [11-15]. Moreover, HenochSchönlein Purpura (HSP) was identified in children with FMF [16].

150 patients $(96 \mathrm{M}, 54 \mathrm{~F})$ with FMF were included in the study by Karakayali A, et al., [17] the most common clinical finding was abdominal pain. In the study by Yavuz S, et al., [18] with 53 FMF patients $(27 \mathrm{~F}, 27 \mathrm{M})$; the most common complaints were fever, abdominal pain and arthralgia. In the study by Çağlar A, et al., [19], with 81 children with FMF, the most common complaints were abdominal pain (98.8\%) and arthralgia (80.2\%).

Approximately 90\% of FMF patients experience disease flares [20]. Most patients are diagnosed before the age of 20 [21]. The onset of symptoms of FMF is usually between 5 and 15 years of age [22]. In a study with 1,633 patients with early onset ( $\leq 20$ age), 613 patients with later onset ( $>20$ age), a total of 2,246 patients from 15 adult Rheumatology Clinics [20].

The most frequently seen mutation among the FMF patients is M694V, which starts at an early age, continues with severe attacks and if not diagnosed or treated early leads to amyloidosis. Colchicine is used regularly after diagnosis which prevents amyloidosis [23]. It was determined by Istanbul Medeniyet University Hospital that the most frequent primary etiological reason for 63 patients diagnosed with AA amyloidosis is FMF (57\%) [24,25].

Colchicine treatment can ensure complete remission among 60$75 \%$ of patients, but $5-10 \%$ of them are resistant to colchicines and the drug is safe to use during pregnancy [26,27]. Drugs used in FMF may be effective on the reproductive system and pregnancy [22].

The most important factor which affects prognosis of FMF patients is whether there are any complications or not, including amyloidosis [28]. In the study by Karakayali A, et al., 146 of 150 patients responded well to colchicine treatment. Amyloidosis was detected in 3 male patients [17].

In cases where the patient is resistant to colchicine, anti-tumor necrosis factor (TNF), anti-interleukin 1(IL-1), IL-6 inhibitor and tocilizumab (TCZ) treatments were safe $[29,30]$.

FMF is mostly seen in regions of Central Anatolia, Western and Eastern Black Sea, Eastern, and Southern-Eastern Anatolia [31]. One out of every four or five people carries the FMF mutation in Turkey [23].

In a study with 704 FMF patients, the illness is widespread in Black Sea and Central Anatolia Regions, especially in Kastamonu, Sivas and Tokat [32] (Figure 4). In another study with 81 FMF children, most incidences were in Sivas, Kastamonu and Ordu [19] (Figure 5).

In a study on 2,838 patients by the TR-FMF study group, the presence of mutations in 1,090 patients, the three most frequent mutation analyses were: M694V (51.4\%), M680I (14.4\%) and V726A (8.6\%) [33]. According to the mutations they carry, patients were divided into four groups (homozygous for M694V, homozygous for M680I, compound heterozygotes, and patients without the M694V mutation), and the phenotype-genotype relationship was analyzed. Consequently, homozygous for M694V the patient became ill at an earlier age and arthritis and arthralgia were observed at a higher rate [34].

In a study by Coşkunpınar E, et al., [34] including 1,840 prediagnosed cases (1059F, 781M) between 2014-2016, 1,180 of the cases had no family history, and 200 of them had mutations in their first degree relatives. The total number of cases with a mutation was 609 . The most common mutations were M694V (48.3\%), E148Q (24\%), M680L (8.7\%) and V726A (5.9\%). No mutation with FMF was detected in 547 of 866 patients in the age group $<18$. No mutation with FMF was found in 477 of 974 patients in the $\geq 18$ age group. In this study, 44 cases were homozygous for M694V. The fact that 23 of the cases were $<18$ years

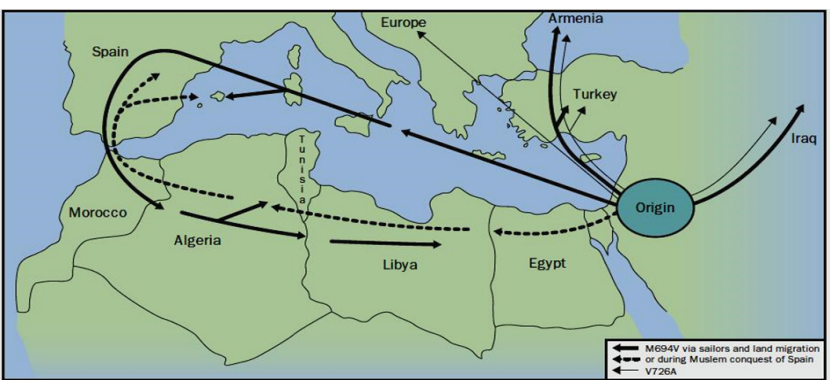

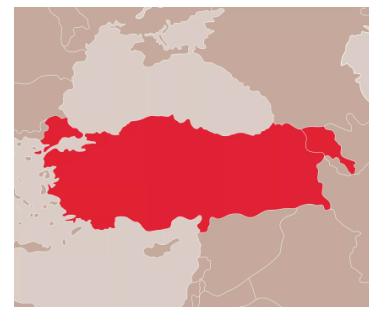

A: Turkey

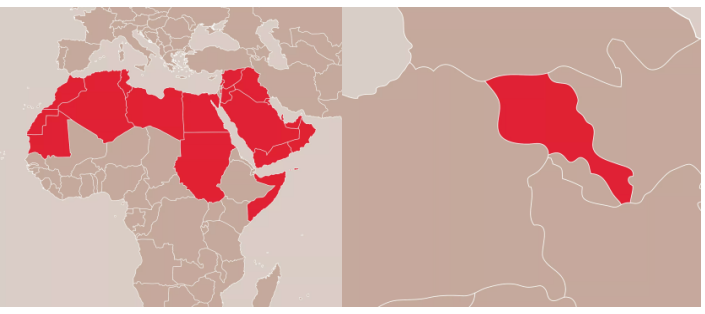

B: Arab Countries
C: Armenia

A: The rate of FMF in Turkey is about $0.1 \%$ [4].

B: Approximately $20 \%$ of the Arabic is an FMF gene carrier [4].

C: The rate of FMF in Armenia is about $0.17 \%$ [4].

Figure 1: Migration map of Familial Mediterranean fever disease. 


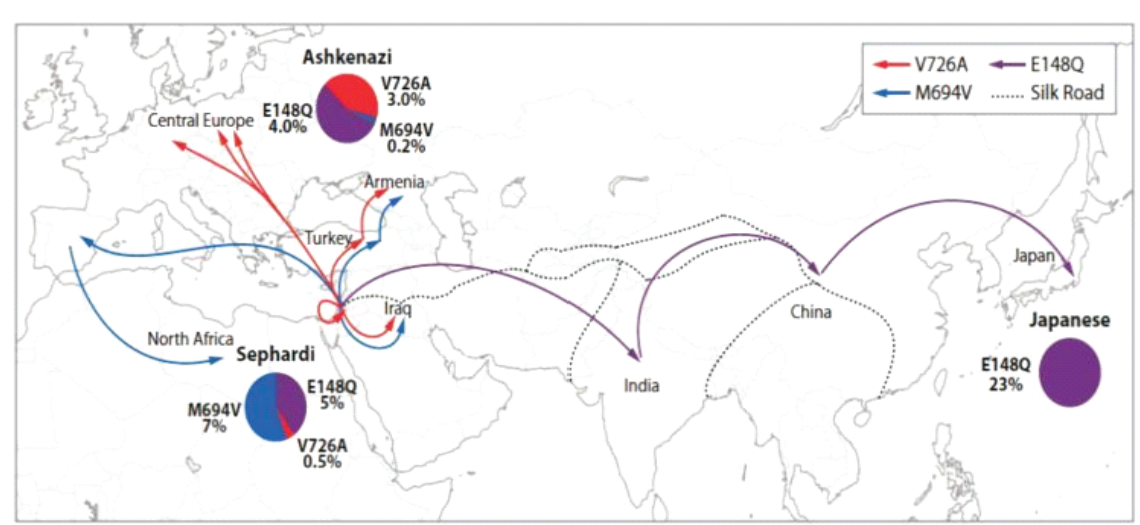

Figure 2: The figure highlights common Pirina mutations in several Mediterranean populations with different types of mutation. The blue and red lines indicate the migration of populations carrying the M649V and V726A mutations respectively, while the purple line shows the E148Q mutation along the medieval Silk Road route. The pie charts indicate the carrier frequencies of selected mutations [7].

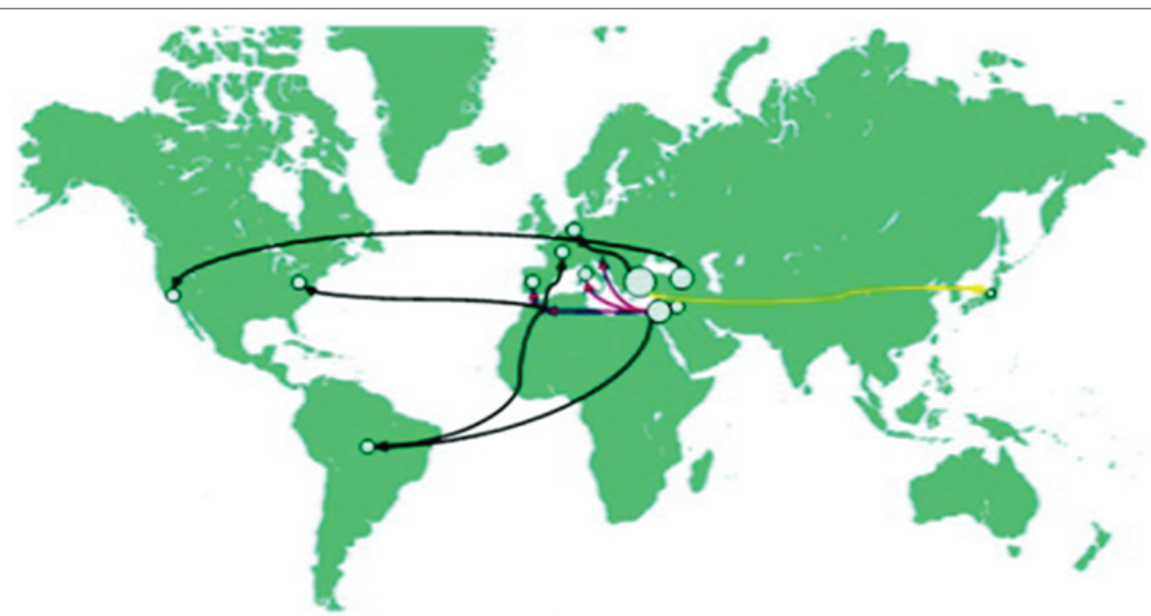

Figure 3: Countries where FMF is common. Circle size is proportional to that of the FMF community in that country. Arrows show spreading of the disease. Red arrows show the migration of the MEFV.

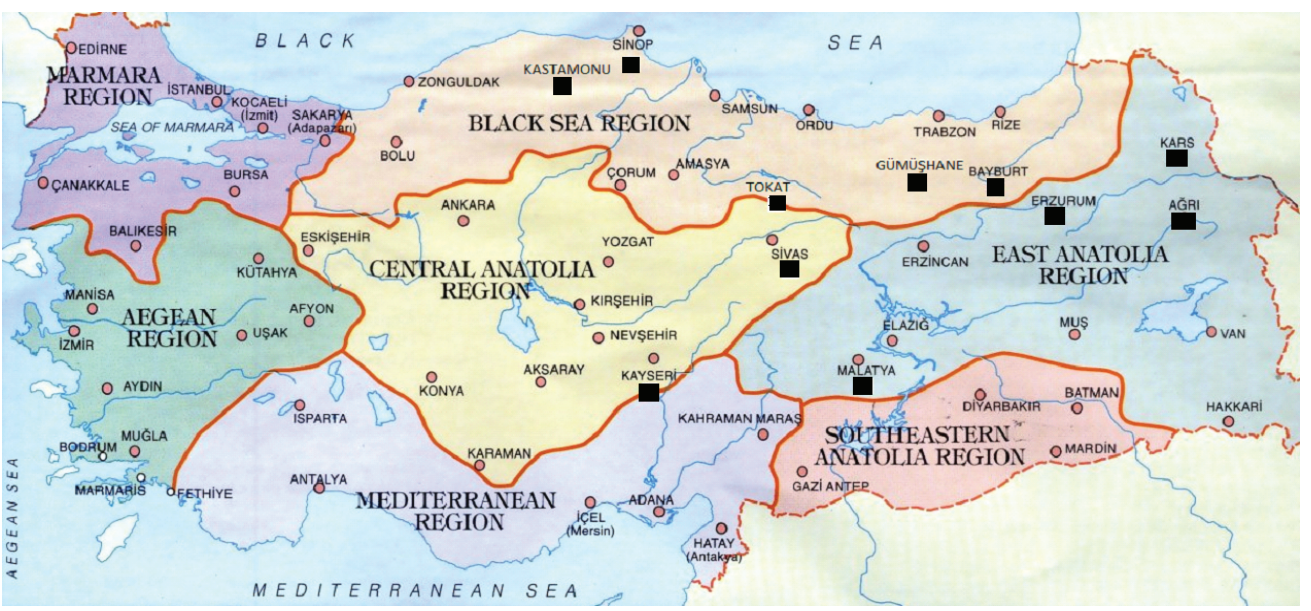

Figure 4: Cities in Turkey FMF is seen [19]. 


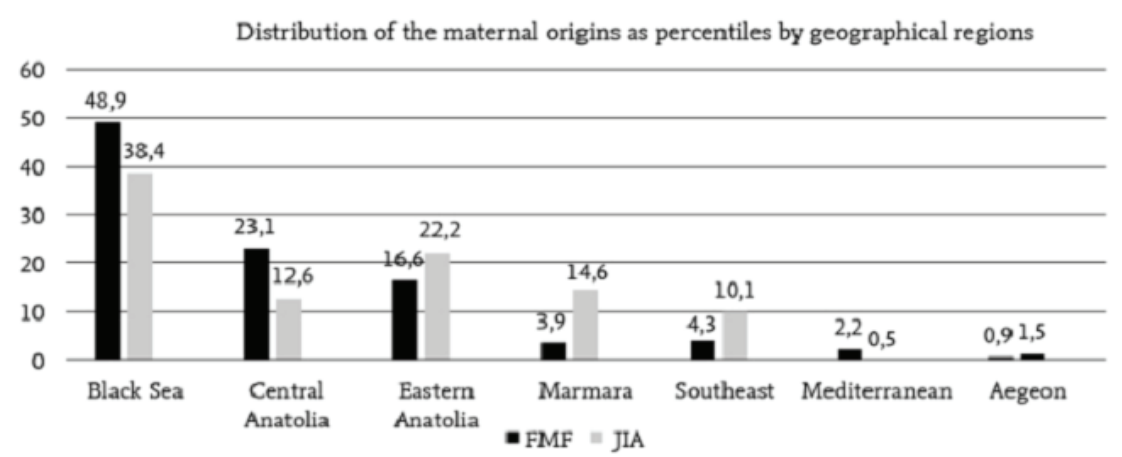

Figure 5: Regions with FMF and juvenile idiopathic arthritis [32].

old and 21 cases $>18$ years old age also corresponds to the results of the TR-FMF study group in terms of the age.

In a study by Karakayali A, et al., [17] on 150 FMF patients, mutation analysis was M694V (51\%), M68QI (18\%), E148Q (7.3\%), V726A (4\%). Moreover, the frequency of amyloidosis and abdominal pain was higher in patients with M694V mutation.

In the study by Yavuz S, et al., [18] the most common mutation among 53 FMF patients was M694V (54.6\%). Also, the disease severity score was higher in patients with M694V homozygous compared with others.

In a study by Caglar A, et al., [19] the frequency of amyloidosis and the severity of the disease was higher in FMF patients with M694V homozygous mutation.

As a result of the study by Cilingir O, et al., [35] at the Faculty of Medicine of Osmangazi University between 2011-2017, mutations were detected in 2,774 of 5,836 patients. The three most detected mutations in 5,836 cases were M694V (18.59\%), E148Q (12.15\%), V726A (7.4\%)

In the cases of FMF, a study by Bayrak M, et al., [36] between 2011 and 2015 with 212 patients $(116 \mathrm{~F}, 96 \mathrm{M})$ with the MEFV mutation to determine types and frequency of MEFV mutations showed that the most common MEFV mutations were M694V (34.9\%), E148Q (26\%), V726A (16\%) and M68OI (8.3\%). Moreover, the distribution of mutations according to gender of FMF patients was as follows: M694V, E148Q, V726A, M68OI and P369S were more frequent in women and M694V, E148Q, V726A, M68OI and R761H mutations were more common in men.

Moreover, the study by Yasar Bilge NS, et al., states that the M694V mutation was higher and the E148Q mutation was lower in FMF patients [20].

A study by Demir AK, et al., between 2015 and 2018 showed that the mutation exists in 161 of 277 FMF patients. The most common were M694V (58.2\%), R202Q (27.6\%), V726A (18.2\%), M68QI (15.3\%), E148Q (10\%) [37] (Figure 6).

In the study including 132 FMF patients in Diskapi Hospital between 2011-2015, anterior uveitis was seen among 3 patients and posterior uveitis in 1. The risk of uveitis was higher in FMF patients with M694V mutation. None of the patients with FMF without MEFV gene mutation had uveitis detected $[38,39]$. To evaluate macular and choroid thicknesses in children with MEFV gene mutation, 35 children with MEFV gene mutation and 40 healthy children as the

\section{Israel}

North African Jews: p.M694V, p.E148Q

Iraqi Jews: p.V726A, p.M694V, p.E148Q, p.M680I

Ashkenazi Jews: p.E148Q, p.V726A

Middle East

Arabs: p.V726A, p.M680I, p.M694V, p.M694I, p.E148Q

Turkey

Turks: p.M694V, p.M680I, p.V726A, p.E148Q

Armenia

Armenians: p.M694V, p.M680I, p.V726A, p.E148Q

Japan

Japanese: p.M694I, p.[L110P; E148Q], p.R761H, p.E84

Figure 6: Most frequent mutations according to various ethnic groups and countries [38].

control group were included, and children with MEFV gene mutations had narrowing of the retinal arterioles, retinal venules, and macular and choroidal thinning [40].

In the evaluation of 9 FMF patients, 5 adults and 4 children, who applied to the cardiology outpatient clinic with chest pain complaints with the K447M mutation carrier, had no cardiovascular involvement, while patients with the M6694V and R202Q composite mutation carrier were at risk of cardiovascular involvement. Therefore, the importance of regular follow-up of FMF patients with mutation carriers in terms of a cardiovascular risk factor was emphasized [41]. FMF was detected in $1.4 \%$ of the patients in the evaluation made on 134 patients (56F,78M) who had complaints of chest pain at Dicle University in 2017 [42].

In another study with 98 children with FMF and 49 healthy children who received colchicine treatment, no significant difference was found between the two groups in terms of vitamin B12 levels. Vitamin B12 levels of patients taking colchicine at a dose of $>1 \mathrm{mg} /$ day were lower than those taking colchicine at a dose of $\leq 1 \mathrm{mg} /$ day [43].

As a result of the study involving 60 patients and 60 healthy individuals who applied to Sivas Cumhuriyet University in 2017, serum prolidase enzyme levels were significantly higher in FMF patients compared to the healthy group. 45 Serum Calprotectin (CLP) levels were significantly higher in FMF patients compared to the healthy group. CLP was an important biomarker in FMF [44]. 
A study by Dogruel D, et al., [45] at Çukurova Medical School with 110 children $(58 \mathrm{~F}, 52 \mathrm{M})$ with FMF received colchicine treatment between 2008-2017. In this study, changes in the mean platelet volume (MPV) during the episodes of FMF with and without attack were investigated. While MPV was $9.61 \pm 1.18 \mathrm{fL}$ in the attack-free period, it was $8.55 \pm 1.51 \mathrm{fL}$ in the attack period. That is, MPV decreased during the attack period of patients. Moreover, $92.7 \%$ of patients had fever, $90 \%$ abdominal pain, $76.4 \%$ joint pain, $10.9 \%$ erysipelas and $9.1 \%$ appendectomy.

In the study by Ozisler C, et al., [46] including $97 \mathrm{FMF}$ patients and a healthy control group of 60 individuals, the neutrophil/lymphocyte ratio (NLR) was higher in FMF patients than those in the control group. There was also a significant correlation between NLR and C-reactive protein during the attack period. The NLR value in the non-ataxia period was higher in patients with M694V homozygous mutation. While MPV was lower in FMF patients compared to the attack-free period, there was no difference between the two groups. During the attack periods of FMF patients, an increase in NLR levels and a decrease in MPV values were observed.

According to the study by Bodur H, et al., [47] consisting of 979 FMF patients (643F, 336M) in 22 centers, patients with homozygous gene mutations had the disease earlier with higher severity as well as the presence of sacroiliitis and amyloidosis. Patients with compound heterozygous genotypes exhibited serious disease activity very similar to patients with homozygous mutations. Besides, they had prolonged febrile myalgia rates and high fibrinogen levels. While $63.9 \%$ of the compound heterozygous patients were at the age of $<20$, there was high disease severity and attack frequency as well as colchicine resistance. Also, $7 \%$ of 585 pregnancies resulted in preterm labor and $18.1 \%$ abortion, and $61.4 \%$ of patients did not have FMF attack during pregnancy.

As a result of a study by Yaşar Bilge NŞ, et al., [48] with 150 FMF patients $(87 \mathrm{~F}, 63 \mathrm{M})$ to examine the relationship between gender and clinical findings, disease severity, and treatment compliance in FMF patients. The rate of erysipelas-like erythema was $31 \%$ and $36.50 \%$, $\mathrm{p}=0.015$ among men with myalgia while $51.70 \%$ and $19 \%, \mathrm{p}=0.03$ among women with myalgia. Also, ISSF scores, clinical findings and treatment compliance did not differ between genders, and gender did not affect prognosis in FMF patients.

In the evaluation of red cell distribution width levels performed by Demir AD, et al., on the control group consisting of 56 FMF patients (35F, 21M) and 30 healthy individuals (19F, 11M) between 2016-2017, no statistical significance was observed between healthy individuals and FMF patients [49].

In the study by Çalişkan Z, et al., [50] to investigate a possible relationship between atherosclerosis and monocyte/ high density lipoprotein (HDL) ratio in FMF patients between 2006 -2018, 40 FMF patients $(21 \mathrm{~F}, 19 \mathrm{M})$ and 35 healthy people $(21 \mathrm{~F}, 19 \mathrm{M})$ were included. Monocyte count/HDL ratio and high sensitivity $\mathrm{C}$ reactive protein levels were higher in FMF patients.

The study by Çakırca G, et al., [51] included 63 patients with FMF and 51 healthy individuals; atherogenic index of plasma (AIP), atherogenic (AC), coefficient (CRI-I) and II levels (Castelli's risk indices) were higher in FMF patients, whereas cholesterol level was observed. In addition, AIP, AK, CRI-I and II levels were higher in male patients with FMF than female patients, whereas platelet, ESR and HDL cholesterol levels were lower.

\section{Diseases Accompanying FMF}

In the study by Demir AK, et al., [37] including 277 FMF patients (176F, 101M) who applied to Tokat Gaziosmanpaşa University between 2015-2018 an accompanying systemic disease was detected in 36 of the patients, while Ankylosing spondylitis was the most common in 7 patients.

In a study by Sönmez HE, et al., [52] to compare the clinical, laboratory and treatment features of Immunoglobulin A Vasculitis / Henoch-Schönlein Purpura (IgAV/HSP) and FMF disease, 114 patients with IgAV/HSP and MEFV analyses were included. CRP value, nonsteroidal anti-inflammatory drug (NSAID) and colchicine treatment rates were higher in IgAV/HSP and FMF patients. In children with IgAV/HSP, the presence of FMF was more common. In an evaluation by Davutoglu EA, et al., [53] between 2013 and 2017 in Istanbul University in which 40 FMF patients' pregnancies were followed up; $90 \%$ of the patients received medical treatment, 7 patients had attacks during pregnancy, the average birth week was $37.3 \pm 4.5$ and the average birth weight was $3,115 \pm 547$ grams. Preterm delivery was $10 \%$, fetal growth restriction was $5 \%$, and the number of preeclampsia incidences was $10 \%$. Fetal and neonatal loss or congenital anomaly delivery was not observed.

A study by Atilgan KG, et al., [54] between 2005 and 2007 to investigate the clinical and laboratory findings of 23 patients with FMF-associated AA-amyloidosis (Group 1) and 36 patients with AAamyloidosis (Group 2) without FMF association. Renal replacement therapy (RRT) requirement were similar in both groups for 5 patients in Group 1 and for 11 patients in Group 2 receiving RRT.

In the study by Kostek O, et al., [55] including 33 FMF patients, 33 secondary amyloid patients and 65 healthy individuals to evaluate amyloid cases with FMF, the carotid intima-media thickness of FMF patients was higher. A subclinical myocardial involvement may have occurred among patients with amyloid secondary to FMF.

Celiac disease is an immune-mediated systemic disease characterized by intestinal villi damage, triggered by gluten intake in genetically susceptible individuals, with different clinical symptoms [56]. Some findings such as diarrhea, abdominal pain, arthralgia and arthritis during the course of celiac disease can also be seen in cases with FMF [57]. Due to this similarity in clinical findings, it is difficult to detect Celiac disease in FMF patients. Therefore, Celiac disease should be taken into consideration among FMF patients if there is a family history [58].

In the study by Zarif NÖ, et al., [59] a 16-year-old female patient with symptoms of recurrent fever, left flank pain, shortness of breath and exudate pleural fluid (PF) samples was diagnosed as M680I (G/C) heterogeneous carrier and oral colchicine treatment was applied to the patient. After the treatment, the patient's clinical condition improved and PF accumulation decreased. The main complaint in 95\% of FMF patients was abdominal pain. Pleural pain was rare without abdominal pain. PF accumulation was even rarer. However, FMF may be the cause of $\mathrm{PF}$ accumulation. In patients with $\mathrm{PF}$ accumulation with chest pain and fever, FMF should be taken into consideration among the differential diagnoses, especially when there is no response to routine nonspecific treatment.

In a study by Yorulmaz A, et al., [60] on protracted febrile myalgia syndrome (PFMS) in 9 patients (7F, 2M) with FMF, between 2016 and 2018, 2 out of the 9 patients had been diagnosed before at the Selçuk University and were receiving colchicine treatment. The first sign of FMF in 7 of the patients was PFMS. Considering the genetic analysis 
of the patients, M694V homozygous was detected in 4 patients. Acute phase reactants were high in all patients. Creatine kinase levels were within normal limits in all patients. Pulse corticosteroid therapy was applied at a dose of $10 \mathrm{mg} / \mathrm{kg}$. All patients completely recovered after the treatment. Thus, PFMS should be taken into consideration in the presence of protracted myalgia and high levels of acute phase reactant with high fever that does not meet FMF criteria.

In the study by Tezcan D, et al., at the Department of Rheumatology between 2017-2018, in which 11 patients (10M,1F) over 18 years of age were diagnosed with Hidradenitis Suppurativa (HS), there were four seronegative spondyloarthropathies, three Behçet's disease, a FMF, a rheumatoid arthritis, a gout, and a SAPHO syndrome (synovitis-acnepustulosis-hyperostosis-osteitis). HSP was associated with rheumatic diseases; therefore, in patients followed up with HSP, there should be a differential diagnosis by examining in case of rheumatological complaints [61]. There is an increase in frequency of vasculitic diseases such as PAN and HSP in patients with FMF. In the FMF gene analysis, homozygous MEFV mutation (M694V/M694V) was detected in a 9-year-old male patient admitted to the hospital with severe abdominal pain and fever. Due to fever, very severe abdominal pain, weakness, and erysipelas-like rash starting around colchicine treatment but not controlled, vasculitic disease in the FMF was evaluated and a positive response was obtained by evaluating the diagnosis of possible PAN [62].

There were 25 FMF cases with Henoch-Schönlein, 25 with genetic, 29 with PAN, 5 undergone transplantation, 1 undergoing dialysis and 25 cases were in the transplantation waiting list in 64 screened articles of San A [63].

\section{The First Drug in FMF Therapy: RPH104}

Ege University developed, "RPH-104" molecular with a TR-PHARM cooperation, Turkey's first biological drug candidate, has successfully completed the "The first human use" clinical phase of the phase- 1 drug research. After comprehensive positive animal studies, clinical trials were started with healthy volunteers, and in these studies, 5 different doses tested the beneficial effect in humans and when reaching the expected level it was interrupted as safe. Some results of the research were presented as a poster at the $9^{\text {th }}$ International FMF and Systemic Auto-Inflammatory Diseases Congress held in the Turkish Republic of Northern Cyprus-Girne on May 4-7, 2017 [64].

\section{Conclusion}

In conclusion, it can be clearly seen that although the name suggests FMF, referring to Mediterranean region, it has been seen more in places other than Mediterranean, in regions of the Black Sea (48.9\%), Central Anatolia (23.1\%), Eastern Anatolia (16.6\%), Southeast (4.3\%), Marmara (3.95\%), Mediterranean (2.2\%) and Aegean (0.9\%) as can be seen in figure 4 , which may be considered surprising.

There was once no cure for FMF and lots of patients suffered from lack of treatment. However, the development of "RPH-104" by Ege University, and a molecule with a TR-PHARM cooperation, Turkey's first biological drug candidate, is definitely considered of utmost importance, enabling many patients to lead healthy lives.

\section{References}

1. Üreten K (2017) Familial Mediterranean Fever: Clinical Manifestations. Turkish Clinics J Rheumatol 10: 13-18.

2. Sarı I, Birlik M, Kasifoğlu T (2014) Familial Mediterranean Fever: An updated review. Eur J Rheumatol 1: 21-33.
3. Sezer I, Kocabaş H (2007) Ailesel Akdeniz Ateşi. Selçuk Tıp Der 24: 209-216.

4. Ailevi Akdeniz Ateşi (FMF).

5. Yılmaz G, Masatlioglu S, Yetkin DO, Demirtunç R, Boysan SN, et al. (2012) Is there a real adrenal axis dysfunction in patients with amyloidosis associated with familial Mediterranean fever? Rheumatol Int 32: 3421-3424.

6. Yalçınkaya F, Örün E (2003) Familial Mediterranean Fever and Amiloidosis in Turkish Medicine. J Turk Soc Nephrol 12: 1-7.

7. Peñaranda-Parada E, Spinel-Bejarano $N$, Restrepo JF, RondónHerrera F, Millán A, et al. (2010) Enfermedades Autoinflamatorias. Rev Colomb Reumatol 17: 86-95.

8. Alghamdi $M$ (2017) Familial Mediterranean fever, review of the literature. Clin Rheumatol 36: 1707-1713.

9. Özdemir AL, Sökmen C (1969) Familial Mediterranean fever among the Turkish people. Am J Gastroenterol 51: 311-316.

10. Özen S, Karaarslan Y, Özdemir O, Saatci U, Bakkaloglu A, et al. (1998) Prevalence of juvenile chronic arthritis and familial Mediterranean fever in Turkey: a field study. J Rheumatol 25: 2445-2449.

11. IIlhan I, Tınaztepe K, Tmaztepe B (1989) Poliartrin's nodaza ve ailevi Akdeniz Ateşi. Çocuk Sağlığı ve Hastalıkları dergisi 32: 151-157.

12. Özen S, Saatçi Ü, Balkana F, Besbas N, Bakkaloglu A, et al. (1992) Familial Mediterranean Fever and Polyarteritis Nodosa. Scand J Rheumatol 21: 312-313.

13. Koçak H, Çakar N, Hekimoğlu B, Atakan C, Akkök N, et al. (1996) The coexistence of familial Mediterranean fever and polyarteritis nodosa; report of a case. Pediatr Nephrol 10: 631-633.

14. Tınaztepe K, Güçer S, Bakkaloğlu A, Tinaztepe B (1997) Familial Mediterranean fever and polyarteritis nodosa: experience of five paediatric cases. A causal relationship or coincidence? Eur J Pediatr 156: 505-506.

15. Oğuzkurt P, Akçören Z, Kale G, Tanyel FC (2000) Polyarteritis nodosa involving the hepatobiliary system in an eight-year-old girl with a previous diagnosis of familial Mediterranean fever. Eur J Pediatr Surg 10: 145-147.

16. Tekin M, Yalçınkaya F, Tümer N, Akar N, Misirlioğlu M, et al. (2000) Clinical, laboratory and molecular characteristics of children with Familial Mediterranean Fever-associated vasculitis. Acta Paediatr 89: 177-182.

17. Karakayali A, Erten S, Akan S, Altunoglu A, Erzurum C, et al. (2017) Demographic, clinical and genetic features of the patients with familial mediterranean fever. J Clin Anal Med 8: 43221.

18. Yavuz S, SelçukDuru N, Elevli M (2018) Relationship Among Clinical, Laboratory Findings, Disease Severity Scores and Genetic Mutations in Patient with Familial Mediterranean Fever. Med Bull Haseki 56: 58-64.

19. Çağlar A, Özçelik G, Akıncı N (2018) Genotype - phenotype correlation in pediatric patients with Familial Mediterrenean Fever. Dr. Behçet Uz Çocuk Hastalıkları ve Cerrahisi 8: 144-150.

20. Yaşar Bilge NS, Sari I, Solmaz D, Senel S, Emmungil H, et al. (2018) Comparison of early versus late onset familial Mediterranean fever. Int J Rheum Dis 21: 880-884.

21. Ben-Chetrit E, Levy M (1998) Familial Mediterranean fever. Lancet 28: 659-664.

22. Solmaz D, Akar S (2018) Familial Mediterranean Fever and Pregnancy. Turkiye Klinikleri J Rheumatol 11: 126-130. 
23. Varduhi Balyan (2019) Turkey and Armenia shared problem: Familial Mediterranean Fever. AGOS, Turkey.

24. Bakan A, Oral A, Ecder SA, Özkök A, Elçioğlu ÖC, et al. (2018) AA Amiloidoz Tanısı Alan Hastaların Etiyolojisinin Retrospektif Olarak Değerlendirilmesi. IKSST Derg 10: 113-116.

25. Ben-Chetrit E, Levy M (1998) Colchicine: 1998 update. Semin Arthritis Rheum 28: 48-59.

26. Michael O, Goldman RD, Koren G, Motherisk Team (2003) Safety of colchicine therapy during pregnancy. Can Fam Physician 49: $967-$ 969.

27. Ditkoff EC, Sauer MV (1996) Successful pregnancy in a familia Mediterranean fever patient following assisted reproduction. J Assist Reprod Genet 13: 684-685.

28. Varan Ö, Babaoğlu H, Tufan A (2019) Prognostic Factors in Familial Mediterranean Fever. In: Göker B (eds) Prognostic Factors in Rheumatological Diseases. $1^{\text {st }}$ edition, Ankara: Turkey Clinics 70-73.

29. Yilmaz R (2019) Innovations in the Diagnosis and Treatment of Familial Mediterranean Fever and Amyloidosis. In: Ersoy FF (eds) New Treatments in Nephrology. $1^{\text {st }}$ Edition, Ankara: Turkey Clinics 34-38.

30. Özdoğan U, Uğurlu S (2019) Familial Mediterranean Fever. Presse Med 48: e61-e76.

31. Albayrak O, Çürük MA (2009) Ailesel Akdeniz Ateşi (FMF). Arşiv Kaynak Tarama Dergisi 18: 260-267.

32. Barut K, Pamuk G, Adrovic A, Şahin S, Kaplan A, et al (2018) Comparison of familial Mediterranean fever and juvenile idiopathic arthritis patients according to family origin. Turk Pediatri Ars 53: 31-36.

33. Tunca M, Akar S, Onen F, Ozdogan H, Kasapcopur O, et al. (2005) Familial Mediterranean fever (FMF) in Turkey: results of a nationwide multicenter study. Medicine (Baltimore) 84: 1-11.

34. Coşkunpınar E, Özvarnalı A, Çefle K, Palanduz A, Gül A, et al. (2018) Molecular Diagnosis Experience in Familial Mediterranean Fever: The Most Frequent Mutations in the MEFV Gene. Med Bull Haseki 56: $42-49$

35. Çilingir O, Durak Aras B, Arslan S, Kutlay Ö, Erzurumluoğlu E, et al. (2018) Distribution of MEFV Gene Mutations and Allele Frequencies in Patients with Familial Mediterranean Fever-One Center Experience. Osmangazi Tıp Dergisi 40: 39-46.

36. Bayrak M, Çadırcı K, Yaralı O (2019) The Frequency of MEFV Gene Mutations for Familial Mediterranean Fever. KÜ Tıp Fak Derg 21: 254-260.

37. Demir AK, Deveci H, Özmen ZC, Kefeli A, Şahin Ş, et al. (2020) Genetic Characteristics of Familial Mediterranean Fever and Its Relationship with Systemic Diseases. Firat Med J 25: 18-22.

38. Ben-Chetrit E, Touitou I (2009) Familial Mediterranean Fever in the World. Arthritis Rheum (Arthritis Care Res) 61: 1447-1453.

39. Köşker M, Çelikay O, Çalışkan S, Biçer T, Özişler C, et al. (2018) The Association Between Uveitis and Familial Mediterranean Fever: Coincidence or Association? Turkiye Klinikleri J Ophthalmol 27: 249254.

40. Battal F, Aylanc H, Yildirim Ş, Ekim Y, Silan F, et al. (2018) Macular and choroidal thickness of children with Familial Mediterranean Fever gene mutation. Fam Pract Palliat Care 3: 23-27.

41. Damar IH, Eröz R (2019) Cardiac Involvement in FMF Patients with New and Rare Mutations. Konuralp Tip Dergisi 11: 274-277.
42. Çiçek P, Akın A, Bilici M, Ture M, Hasan B, et al. (2019) Etiological Evaluation of the Patients Attending to the Pediatric Cardiology Clinic with Chest Pain. Dicle Med J 46: 283-288.

43. Bayram M, Derin ME, Doğan HO, Asan G, Şahin M, et al. (2020) High prolidase levels in patients with Familial Mediterranean Fever (FMF). Rom J Intern Med 58: 27-33.

44. Asan G, Derin ME, Doğan HO, Bayram M, Şahin M, et al. (2020) Can Calprotectin Show Subclinical Inflammation in Familial Mediterranean Fever Patients? J Korean Med Sci 35: e63.

45. Doğruel D, EkinciKışla RM, Balcı S, Yılmaz M, AltıntaşUfuk D (2019) Clinical Importance of Mean Platelet Volume in Children with Family Mediterranean Fever. ACU Sağlık Bil Derg 10: 589-592.

46. Özişler C (2019) Evaluation of Neutrophil to Lymphocyte Ratio and Mean Platelet Volume in Attack and Attack-Free Periods in Familial Mediterranean Fever Patients. Turkiye Klinikleri J Med Sci 39: 179186.

47. Bodur H, Yurdakul FG, Çay HF, Uçar Ü, Keskin Y, et al. (2020) Familial mediterranean fever: assessment of clinical manifestations, pregnancy, genetic mutational analyses, and disease severity in a national cohort Rheumatol Int 40: 29-40.

48. Yaşar Bilge NŞ, Bodakcı E, Bilge U, Kaşifoğlu T (2019) Gender is not a Prognostic Factor for Familial Mediterranean Fever. Ankara Med J 4: 716-721.

49. Demir AD, Durmaz ZH, Guckan R, Kilinc C, Demir O (2019) Coevaluation of Red Cell Distribution Width Changes in Different Group of Familial Mediterranean Fever Patients. Eurasian J Med 3: 41-45.

50. Çalışkan Berkdemir Z, Çakıllı Telci O, Yılmaz Y, Çalıskan M (2019) Association Between Atherosclerosis and Monocyte/High Density Lipoprotein Ratio in Patients with Familial Mediterranean Fever. Med Med J 34: 194-199.

51. Çakırca G, Çelik MM (2018) Lipid profile and atherogenic indices and their association with platelet indices in familial Mediterranean fever. Turk Kardiyol Dern Ars 46: 184-190.

52. Sönmez HE, Batu ED, Bilginer Y (2018) The Increased Frequency of Familial Mediterranean Fever in Patients Diagnosed with Immunoglobulin a Vasculitis (Henoch-Schönlein Purpura). Güncel Pediatri 16: 35-46.

53. Davutoğlu EA, Özel A, Erenel H, Madazli R (2018) Perinatal Outcomes of 40 Pregnancies with Familial Mediterranean Fever. Zeynep Kamil Tıp Bülteni 49: 77-79.

54. Atilgan KG, Odabaş AR, Dede F, Ayli MD (2018) Analysis of Clinical and Laboratory Findings of Secondary Amyloidosis. Turk Neph Dial Transpl 27: 267-271.

55. Köstek O, Takir M, Çalişkan M, Oğuz A (2018) Assessment of cardiovascular findings in FMF related amyloid patients. Med Med J 33: 149-157.

56. Husby S, Koletzko S, Korponay-Szabo IR, Mearin ML, Phillips A, et al. (2012) European Society for Pediatric Gastroenterology, Hepatology, and Nutrition Guidelines for the Diagnosis of Coeliac Disease. J Pediatr Gastroenterol Nutr 54: 136-160.

57. Mor A, Gal R, Livneh A (2003) Abdominal and digestive system associations of familial Mediterranean fever. Am J Gastroenterol 98: 2594-2604.

58. Şahin Y, Kocamaz H, Özen E (2017) Is It a Two Variable Equations?: A Rare Association of Familial Mediterranean Fever and Celiac Disease. The Medical Bulletin of Sisli Etfal Hospital 51: 252-254. 
59. Zarif NÖ, Örmeci AR (2018) A Cause of Recurrent Pleural Effusion is Familial Mediterranean Fever. J Pediatr Inf 12: 153-155.

60. Yorulmaz A, Akbulut $H$, Arslan ş (2018) Familial Mediterranean fever presenting with prolonged Febrile Myalgia Syndrome: Clinical, Laboratory and Demographic Features of 9 Patients. J Contemp Med 8: 227-232.

61. Tezcan D, Limon M, Gulcemal S, Yilmaz S (2020) The importance of hydradenitis süpürativa in romatological diseases. Journal of Istanbul Medical Faculty 83: 275-279.
62. Yılmaz Ağladıoğlu S, Bakkaloğlu Ezgü S, Peru H, Fidan K, Önal B, et al. (2008) Ailevi akdeniz ateşi ve poliarteritis nodoza birlikteliğiolan pediatrik bir olgu sunumu. Gazi Tip Dergisi 19: 144-146.

63. San A (2018) Historical Development of FMF between 1957-2018 and its Evaluation with Cases. $46^{\text {th }}$ International Medical History Congress, Lisbon.

64. Drug Development and Pharmacokinetics Research-Application Center. Ege University. 